
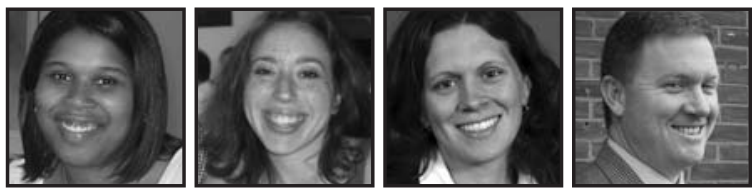

\title{
Examining Ways in Which Youth Conferences Can Spell Out Gains in Community Youth Development and Engagement
}

\author{
Felicia C. Sanders, Marcela A. Movit, Dana L. Mitra \& Danny F. Perkins \\ Pennsylvania State University
}

\begin{abstract}
With student outcomes increasingly becoming associated with test scores, schools are less able to dedicate themselves to helping students learn how to become engaged and active participants in a democracy. As a result, other community-based organizations have stepped in to help students acquire the sense of agency, belonging, and competence-known as the " $\mathrm{A}, \mathrm{B}, \mathrm{C}$ 's" of youth development-that research has shown to be crucial for youth to become contributing citizens. Drawing on survey, interview and observational data, this paper considers how two such organizations give students an opportunity for personal development, while providing youth with leadership skills and opportunities to engage in their schools and communities. This research suggests that in addition to the traditional " $A, B, C$ 's," it may be beneficial to consider aspects of diversity-proposed here as " $D$ " - that play an important role in youth development, as well as the synergy of all four components of youth development that result in positive student outcomes.
\end{abstract}

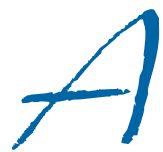

$s$ the pressure to equate student outcomes with test scores increases, the broader democratic mission of schools to prepare students to be engaged and contributing citizens (Dewey, 1916; 1966) is fading into the background. Although public schools on the whole are successfully linking students to community service activities (Flanagan \& Faison, 2001; Honig, Kahne, \& McLaughlin, 2001), 
most fall short when it comes to providing students with opportunities to learn how to become citizens prepared to actively engage in their communities and participate in democracy (Kirshner, 2004; Larson, 2000). Perhaps, then, it is no surprise that high school students frequently describe their school experiences as anonymous and powerless (Earls, 2003; Heath \& McLaughlin, 1993; Pope, 2001). To make matters worse, alienation results in two-thirds of students being disengaged from high schools (Cothran \& Ennis, 2000). Disengaged students attend school less, have lower self-concepts, achieve less academically, and are more likely to drop out of school (Fullan, 2001; Noguera, 2002).

Schools often do not provide sufficient opportunities to prepare youth for adulthood beyond core academic subjects. Community-based organizations frequently try to fill the gap by offering youth a broader range of learning opportunities, including participation in decision-making processes in government agencies, foundations, businesses, and even in schools. Research indicates that youth benefit greatly from engagement in decision-making, and that they can make a difference in their own lives and in the lives of others (Kirshner, O'Donoghue, \& McLaughlin, 2003; Mitra, 2004; National Research Council, 2002). Youth also can develop competencies that are critical for becoming involved and productive citizens. These competencies include tolerance, the ability to get along with others and to respectfully and effectively question authority, and public speaking. Participation also increases youth attachment to schools, which in turn correlates with improved academic outcomes (Eccles \& Gootman, 2002).

Youth engagement in decision-making processes offers benefits to the organizations involved as well. A wide array of organizations, including government agencies, foundations, community-based groups, and businesses, have found that having youth participate in decision-making processes have helped them to become more connected and responsive to issues affecting youth (Zeldin, Kusgen-McDaniel, Topitzes \& Calvert, 2000). Youth-adult partnerships can spark great strides in an organization's vision and accomplishments (Kirshner, O'Donoghue, \& McLaughlin, 2002; National Research Council and Institute of Medicine, 2002; Zeldin, 2004; Zeldin, Camino, \& Mook, 2005). School-based youth-adult partnership initiatives have served as a catalyst for change in schools, by helping to improve teaching, curriculum, and teacher-student relationships and by promoting changes in student assessment and teacher training (Mitra, 2003; Oldfather, 1995; Rudduck \& Flutter, 2000).

While the benefits of youth engagement are documented in the literature (even though there is limited empirical research), many youth lack the skills and the 
competencies to effectively participate in decision-making situations (Mitra, 2004). They tend to need explicit preparation to be able to interact effectively in adult-dominated environments (Mitra, in press). One avenue for providing this preparation is in youth conferences. This article examines the ways in which youth conferences have the ability to improve community youth development outcomes.

\section{Conceptual Framework}

Youth development is a process that prepares young people to successfully navigate the transition to adulthood. Community youth development can help young people achieve their full potential by providing them with opportunities to develop "social, ethical, emotional, physical, and cognitive competencies" (National Alliance for Secondary Education and Transition, 2005). To satisfy the many goals of community youth development, youth need to be involved more deeply than simply "being heard." They need opportunities to influence issues that matter to them (Costello, Toles, Spielberger, \& Wynn, 2000; Pittman, Irby \& Ferber, 2000) and to engage in active problem solving (Fielding, 2001; Goodwillie, 1993). They also need to develop closer and more intimate connections with both adults and peers (McLaughlin, 1999; Pittman \& Wright, 1991).

A "community youth development" framework emphasizes the value and the importance of increasing youth voice and leadership in decision-making processes (McLaughlin, 1999). Building on lessons learned from the 1980s when the emphasis was on "prevention" of problems, youth development scholars now believe that a primary focus on avoiding dangers, such as drugs or sexual activity, diverts attention from understanding the competencies that adolescents do need to be prepared for the future (Cahill, 1997; Connell, Gambone, \& Smith, 1998, Pittman \& Cahill, 1992, Pittman \& Wright, 1991). A youth development perspective is needed so that researchers, policymakers and practitioners focus on the developmental needs of adolescents and the means by which institutions and organizations might address them (Villarruel, Perkins, Borden, \& Keith, 2003).

A youth development framework also offers a lens for conceptualizing the types of changes that one might see as youth participate in youth leadership activities. For instance, recent research has shown that youth need opportunities to influence issues that matter to them (Costello et al., 2000; Pittman, Irby \& Ferber, 2000; Villarruel et al, 2003); to engage in active problem solving (Fielding, 2001; Goodwillie, 
1993; Takanishi, 1993); to develop closer and more intimate connection with adults and with peers (McLaughlin, 1999; Pittman \& Wright, 1991; Takanishi, 1993); and to assume more active classroom roles (Costello et al., 2000).

Our research draws upon three concepts for understanding youth experiences through student voice-agency, belonging, and competence. These three concepts are referred to informally by some youth development researchers and advocates as the "A, B, C's" of youth development (Carver, 1997). The choice to focus on agency, belonging and competence to reflect youth development outcomes derives from research in the fields of both psychology and youth development. Our research is based on the assets that youth need to succeed in school and in their lives overall. Drawing on previous research by Mitra (2003), Table One provides a summary of these three components of youth development, including a brief definition of each term and of the specific ways that youth embodied these assets as they engaged in their student voice activities.

Table 1.

Definitions of Youth Development Assets (Mitra, 2003)

Youth development asset Conceptual definition

Agency Acting or exerting influence and power in a given situation

Belonging

Developing meaningful relationships with other students and adults and having a role at the school

Competence

Developing new abilities and being appreciated for one's talents

Research in developmental psychology supports the finding that agency, belonging and competence are necessary factors for adolescents to remain motivated in school and to achieve academic success (Eccles \& Gootman, 2002; Eccles, Midgley, Wigfield, Buchanan, Reuman, Flanagan, et al., 1993; Goodenow, 1993; Roeser, Midgley, \& Urdan, 1996; Stinson, 1993). The youth development field does not provide a consistent set of assets that youth need to be prepared for the future and to navigate their current situations. The most consistent set of factors include "confidence and compassion; connection and caring; competence and character" (Eccles \& Gootman, 2002; Lerner 2004; Roth \& Brooks-Gunn 2000). Other lists include "autonomy, 
belonging, and competence" (Schapps, Watson\& Lewis, 1997), "self-worth, belonging and competence" (Kernaleguen, 1980), "knowledge, belonging and competence" (Villarruel and Lerner 1994), and "navigation, connection and productivity" (Connell, Gambone \& Smith, 1998). We have chosen the Mitra typology because it is parsimonious. Our inquiry builds out of previous research conducted by Mitra (2003). And, after considering all of the possible choices discussed here, we found that Mitra's typology best fits the data in this study.

\section{Methodology}

This study examines the efforts of two youth leadership organizations, namely, Go the Distance and Reach for Change, which were working to build community youth development outcomes. The unit of analysis was each young person participating in the conference. Both organizations offered four-day leadership institutes free of charge to high school students and their adult mentors in the late spring of each year. Through lectures, interactive activities, small-group work, and discussions, the institutes strengthened individual and teamwork skills while fostering the creation of team projects related to school and/or community improvement. Student teams then worked to implement their projects back in their home communities. Five student groups from five schools were included in the Go the Distance sample. Each group of five students came from the same school. There were also five groups of 10 students included in the Reach for Change sample and these students attended different high schools across the central region of the state.

Over the course of the four-day conference, students from the Go the Distance conference were immersed in team-building activities with school-based teams. One or two faculty advisors and five students from each school participated. On the first day, students participated in icebreaker activities, so that they would become more acquainted with their mentors, their team members, and the other conference attendees. On the following two days, students attended personal development and team-building seminars. Some of these seminars focused on communication, personality exploration, and diversity. Other sessions provided students with time to develop a project that would be taken back to their school and implement over the course of the following year. During these sessions students also received counseling from local business leaders about resource strategy generation to support their project plans. On the last day, the students participated in a final teambuilding activity and presented their project proposals to the conference participants. 
During the following year, the Go the Distance groups received intensive guidance from school faculty mentors as they implemented their projects. In addition, other conference staffers provided ongoing technical assistance through regular communication (2-4 times) with the teams to help them succeed in implementing their projects.

The structure of the Reach for Change group was somewhat different. Students who participated in the Reach for Change conference, upon arrival, were placed immediately into teams of ten students. A majority of these students did not know their team members, nor did they come from the same school. Furthermore, instead of having faculty mentors, students in the Reach for Change conference were mentored by "Near Peers" and "Near Peer Interns". Near Peers were college students. Some of them had participated as high school students in the Reach for Change conferences in the past. Near Peer Interns were high school students who had participated in the Reach for Change conference in the previous year. Both Near Peers and Near Peer Interns were responsible for fostering a positive group dynamic within the team and for facilitating the development of a "pseudo" group project. We use the term pseudo because although student teams were responsible for developing a plan for their projects, they were not required to implement the project once they returned to their respective schools. In Reach for Change, the training and support ended at the completion of the leadership institute.

Interview questions and observational protocols were designed to examine the intentions, structures, and outcomes of the conferences. Since each conference focused on teams of students working on a project, we shadowed, for the duration of each conference, six teams at the Go the Distance conference and five teams at the Reach for Change conference. Where possible, teams that reflected diversity were chosen. The choices were based on geography (i.e., rural, suburban, and urban), economic status (e.g., level of free or reduced lunch at the school), and past experience with the project (e.g., whether or not the school had previously attended the institute).

Members of our research team conducted the observations. During the meetings, researchers transcribed the conversations in as much verbatim as possible using their laptop computers. They also made note of unspoken emotions, gestures, and any undercurrents happening during the meetings. When direct transcription was not possible (such as instances in which the participants were engaged in team building activities involving movement), the researcher took notes and later transcribed these as soon as possible. 
The research team was granted greater access to the Go the Distance groups than to the Reach for Change groups. Thus, in the Go the Distance teams, we were permitted to conduct focus group interviews with the youth and with their adult advisors. We also conducted follow-up interviews with the young people and adult advisors of our selected case studies during the following school year. Additionally, because of the ongoing technical assistance provided by Go the Distance staffers, we were able to record all telephone conversations that occurred between these staffers and the corresponding school teams during the following school year and to track progress and learn about the successes and struggles of the teams.

At the Reach for Change conference, the student groups were observed, but the research team was not permitted to conduct focus-group interviews with the students. Instead, two members of our research team served as participant observers during the conference. Both were appointed as Near Peers to one of the youth teams. The researchers were given digital recorders and, when they had the opportunity to do so, entered comments and reflections about the conference into the recorders throughout the day. They also provided longer briefings of their daily experiences in the evenings. Upon completion of the conference, they both wrote extended memos reflecting on the intention, processes, and outcomes of the conference. Also, They participated in an extended interview with the principal investigator of the project.

The analysis of the data began with the conceptual framework of community youth development conceived in previous research (Mitra, 2003). We expected that the new data would help us revise and improve the previous work (Miles \& Huberman, 1994; Strauss \& Corbin, 1990). Special care was taken to search for discrepant evidence and claims considered to be contradictory to the original framework. Using NVivo software, all of the interview and observational data were coded based on a coding tree designed to highlight our main research questions for the overall study: (1) What were the intentions of the youth leadership conferences? (2) What were the enacted activities and processes that occurred during the conferences? (3) What were the intended outcomes for youth? (4) What were the actual outcomes for youth? As a result, our coding tree included the following categories: intended and enacted youth outcomes, group process of the youth teams, intentions and actions of the youth teams, and intentions and actions of the non-profits, or organizations that hosted the conferences.

We decided to focus the research findings for this article on the intended and actualized outcomes of youth in both conferences. Next, we engaged in a process of axial coding that defined the relational nature of the outcomes of youth 
by identifying their properties and dimensions. This helped to reduce the themes into key representational categories (Becker, 1998; Strauss \& Corbin, 1990). By moving back and forth between the categories and the original theoretical framework of the need for agency, belonging and competence for youth, we were able to create a typology of youth outcomes (Miles \& Huberman, 1994).

\section{Findings}

We examined the data to learn more about the intended outcomes that the two non-profit groups hoped the youth would achieve. Then we looked at the youth responses and experiences to identify the actual gains in community youth development outcomes. We found that overall, the intended outcomes aligned well with the actual experiences of young people at both conferences. The outcomes themselves fit with previous research of growth in agency, belonging and confidence (A, B, C), with one exception. In the Go the Distance groups, the youth also gained positive experiences in learning about and interacting in diverse environments, which we describe as the " $\mathrm{D}$ " in the $A B C D$ s of youth development (See Table 2 for a description of the activities at the two conferences and whether or not the activity provided the youth with a positive outcome). We also found that, although youth outcomes were best described as the "ABCDs" of youth development, youth indicated that the experiences were most meaningful when these outcomes converged. Thus, a synergy of community youth development outcomes appears to have a deeper impact upon young people. 
Table 2:

Conference Activities and the Impact of Developing Community Youth Outcomes

\begin{tabular}{|c|c|c|c|c|}
\hline \multirow{2}{*}{ Conference } & \multicolumn{2}{|l|}{ Go the Distance } & \multicolumn{2}{|l|}{ Reach for Change } \\
\hline & Activities & Impact & Activities & Impact \\
\hline Agency & $\begin{array}{l}\text { Icebreakers, team } \\
\text { building activities, } \\
\text { leadership seminar, } \\
\text { development of a } \\
\text { project, and working } \\
\text { with adults. }\end{array}$ & Yes & $\begin{array}{l}\text { Quest: a group activity } \\
\text { that requires youth to } \\
\text { complete as many } \\
\text { challenges as possible } \\
\text { in a certain amount of } \\
\text { time. }\end{array}$ & Yes \\
\hline Belonging & $\begin{array}{l}\text { Working with a faculty } \\
\text { mentor, building } \\
\text { relationships with team } \\
\text { members and other } \\
\text { conference attendees, } \\
\text { and icebreaker activities. }\end{array}$ & Yes & $\begin{array}{l}\text { Quest, icebreaker } \\
\text { activities, activities that } \\
\text { encourage the creation } \\
\text { of a shared experience, } \\
\text { and the development of } \\
\text { a group project. }\end{array}$ & Yes \\
\hline Competence & $\begin{array}{l}\text { Professional develop- } \\
\text { ment seminars, such as } \\
\text { communication and } \\
\text { group-work seminars. }\end{array}$ & Yes & $\begin{array}{l}\text { Increased leadership } \\
\text { skills, teamwork skills } \\
\text { and communication } \\
\text { skills through the group } \\
\text { project. }\end{array}$ & Yes \\
\hline Diversity & $\begin{array}{l}\text { The inclusion of people } \\
\text { from different } \\
\text { backgrounds and the } \\
\text { participation in an } \\
\text { in-depth discussion of } \\
\text { diversity issues with } \\
\text { trained college students. }\end{array}$ & Yes & $\begin{array}{l}\text { The Tolerance Troup, a } \\
\text { theatrical play that } \\
\text { exposes the negative } \\
\text { consequences of } \\
\text { stereotypes. }\end{array}$ & Yes \\
\hline
\end{tabular}

\section{Agency}

Agency refers to the ability of students to "[act or exert] influence and power in a given situation" (Mitra, 2004, p. 655). By helping students recognize that they have control over their lives, students are empowered to make changes in their own lives and in their communities (Perkins, Borden, Keith, Hoppe-Rooney, \& Villarruel, 2003). By putting their newfound capacity to work, students learn to construct situations in which they are able to work on their own behalf. 
One of the primary goals of the Go the Distance conference was to provide students with a sense of agency. The Go the Distance staff provided students with personal development seminars and, through self-exploration, students developed agency. This aspect of self-exploration went beyond simply providing students with the basic principles of leadership. Patricia, the director of the Go the Distance conference, explained this process of self-exploration as a unique aspect of the conference and claimed that it set their conference apart from others:

I think what makes ours different is two things. One is that we make kids accountable for doing something with the information that they get. We really do teach a lot during the four days about who you are as a person: What are your strengths and weaknesses? Who are you as a team member? Who are you as a team player on this team and on other teams if you think about it? How do you share your vision? How do you present your ideas to people and does the way you stand give a message? And if it does, you need to know what it is. And we sort out all their foundations and principles. But more than that, we really help kids to feel like they are empowered to make the difference.

The end result of both the self-exploration and team building seminars was to help students become aware of their personal characteristics, which proved to be an empowering experience. Once they understood themselves and how they work with others, they became more confident. This was evident in their ability to go back home and implement their proposed projects.

As mentioned above, agency is described as having the power to influence a situation or to assert one's opinion. Students who attended the Go the Distance conference repeatedly mentioned their increased self-confidence and ability to take on leadership roles as a result of the conference. For example, one student mentioned that as a result of Go the Distance, "...this program helped me recognize the leader that is inside of me, and I think it was there before, but I just didn't want to notice it and that always made me decide to be the follower, but this program help me expand my knowledge and increase my feelings as a leader."This student's comment was typical of the sentiments expressed by many of the students who attended the conference.

The students' newfound sense of agency was carried into their interactions with students the following school year after the Go the Distance conference. One young woman stated in a follow-up interview that she was: "Not afraid to talk to 
somebody now. If we got new kids this year, it's easier to go up to somebody and you don't do the bending over and shaking their hands" (one of the icebreaker activities). It involved having students greet a conference attendee they did not know with a "silly handshake."A young man who attended the conference exemplified his new sense of agency when, in a follow-up interview about six months after the conference, he stated that:

I think one of the things I learned was just to be more open. I was going to business math once and these kids were pushing each other in the halls and I just kind of separated them. But it didn't really work. I mean I tried. I attempted to, but they just pushed past. But I tried. Before I went to this conference, I wouldn't have done stuff like that.

Even though he was unsuccessful in breaking up the fight, when asked if he would attempt it again, he responded "yes." The Go the Distance leadership conference empowered its attendees. They were not only willing to take on more leadership roles in their schools, but they actually took on more risks in asserting themselves in front of the student body.

Similar to the Go the Distance conference, the founder of the Reach for Change conference stressed that helping students acquire a sense of agency was a crucial component of their experience. When asked how he knew that the program had been successful, the founder described a situation about an individual student (not a team) who went home and carried out the project she had helped to design, even though the Reach for Change conference did not require students to implement the project. He explained that the conference helped students to break down the mentality of the "command and control leadership" of the past. Students were encouraged not to wait until they were called upon to lead before becoming leaders. One of the conference coordinators explained:

It really does have a powerful impact on the kids in terms of what they're able to do in a short period of time with strangers, which gives them a confidence that allows them to go back to their schools and try to do the same thing.

In conveying to students the idea that they have the power to change their communities, the conference helped students gain a sense of agency that encouraged them to become leaders in their communities. 
Students' experiences throughout the conference reflected the type of agency the director envisioned. One student shared that he hoped all of the students in his group would take their projects back to their neighborhoods and implement them. Another reported that one of the most important things she learned from the conference was how to take more initiative in a group. Several students expressed that they felt that one of the benefits of the program was that it showed them that students are able to develop feasible projects that they can implement in their schools. Moreover, in consulting with members of the community to advance the projects, students realized the importance of alliances and working in cooperation with other groups in the community to achieve their goals, rather than working in isolation.

\section{Belonging}

Belonging refers to a sense of fitting into one's environment. It involves the creation and maintenance of a community in which meaningful relationships develop among students and between students and adults. Students "see themselves as members with rights and responsibilities, power and vulnerability, and begin to act responsibly, considering the best interests of themselves, other individuals, and the group as a whole" (Carver, 1997, p. 146). In this situation, a sense of social responsibility develops for members of the group.

Another goal of the Go the Distance conference was to help students develop a sense of belonging among their school-based teams. The conference helped students achieve this goal, and the conference directors envisioned students returning to their schools to spread this sense of belonging among their classmates. Patricia, the director, described a project that helped students throughout an entire school to achieve that very goal:

I think some schools do a really phenomenal job of that [bringing students together] and they've really bridged that gap in their school for some kids. Kennett High School outside of Philadelphia is doing the bilingual buddy system that they started four years ago, that now is a couple of hundred kids large. After school it went from one afternoon a month to three afternoons a week, just amazing work ... So the kids are really building this bond and this connection.

The Go the Distance conference encouraged students to develop meaningful relationships through the team-building seminars. The icebreakers helped students 
increase their comfort level with their team members and the students from other schools.

Over the four days of the conference, there were many activities and opportunities for youth to interact with students from other schools. Students overwhelmingly mentioned that they had made new friends throughout the conference. In the students' exit surveys, one of the most common comments about how they benefited from the conference was that they made connections with other peers. One student commented, "The thing I benefited the most was making a lot more friends!" and another student stated that, "I am usually shy, but coming here and meeting new people, I learned to step out of my 'comfort zone' and most the time I was here I hung out with new friends and was very open to new things." The abundance of comments about making new friends speaks volumes to the importance of having a sense of belonging.

Another important aspect of having a sense of belonging as a result of the Go the Distance leadership institute was the bonding of the school-based teams. The institute staff encouraged faculty mentors to select students to attend the conference from the various social groups that existed within their school. The hope was that, when students spent four days with other students from their schools who they did not know very well, it would help build a school-wide community. This appeared to happen when, for example, one student stated that, "I have learned more about myself, and my team and I have gotten closer to them" and another student commented that, "We have been able to come together and compromise. Our group had time to get to know each other better and know what everyone was going for."

As mentioned earlier, a central aspect of the leadership institute required students who attended the conference to implement their projects in their schools and to recruit other students to get involved. One student believed that her sense of belonging helped her group implement its project once the team returned to school: "My team has been able to become closer and work together more as a team. It also shows us how we can connect with others and how we can help other people connect."

Other students reported the conference made it easier for them to open up to people. One student reported that:

And just being here and opening yourself up to people you don't know is a lot of fun surprisingly, and it's a privilege to do this, because I don't do that 
when I am at home. When I made friends I kind of wanted to get to know them first, before I went and spilled my guts out to them. But now, I'm not afraid to do that because I realize it's kind of good to open up to people ... they probably could have something in common. If you had a dark patch, you could talk about it and help each other. There are so many benefits to being an open person. And I'm just glad that I was able to come here and learn to be that way.

During the same focus group with "East Tree" High School, one student repeatedly commented that she only had one friend at her high school. At the time of the conference, she had recently regained her hearing, after being deaf for many years. Her disability was somewhat of a barrier in making friends and the Go the Distance conference helped her overcome that obstacle. When asked if she benefited from the conference, she responded: “Yeah, I got away from my one friend kind of. It made me want new friends.... I used to be really reserved, like real quiet. I'm not really like that any more. I'm more outgoing." During the same conversation, her other team members commented that they had noticed a change in her and they felt that she was also their friend.

In direct contrast to the specific focus on developing a sense of belonging that was a critical part of the Go the Distance conference, this was not one of the stated purposes of the Reach for Change conference. However, the bonds that formed were a crucial component of the success of the conference. The director explained that the youth shared more over the course of the four days at the conference than they had realized. One of the program coordinators related, "It's amazing. The last day, people were crying their eyes out because they're leaving these people. And I'll tell you some incredible friendships developed over such a short period of time."

Through the observations and talking with students, it became clear that the youth felt a strong sense of belonging at the Reach for Change conference. One student expressed amazement because he "didn't know so many people cared about the same things [he] did"; he felt that one of the most positive things about the conference was that:

A lot of us came from our same school, but we didn't stay in our own groups; we got paired up instead by our interests. I met so many people I would have never even talked to before if we were in the same school. 
Students also formed close friendships with students from other schools. One student explained that at first she was hesitant about how people, who were so different, would be able to get along. Nevertheless, she quickly realized that she was able to relate to her group members better than she did with most of her friends and she felt like she had known her teammates her entire life.

\section{Competence}

Competence can consist of many different skills and talents. According to Carver (1997), developing competence means, "learning skills, acquiring knowledge, and attaining the ability to apply what is learned" (p. 146). Students developed a variety of competences in both the Go the Distance and Reach for Change conferences. These skills included an increased ability in both communication and leadership.

In the case of Go the Distance leadership institute, students believed that their increased ability to communicate effectively was a significant outcome of the conference. Students were constantly engaged in activities that required them to communicate with their school group, as well as students from elsewhere. Students were also required to speak in front of the large group of 200 students as well as within smaller groups. Overall they really appreciated these activities and the opportunity to increase their communication skills. Some of the students' comments about communication included:"It has helped me become a better public speaker," "I have learned to communicate and be open;" and, "I know how to communicate and trust one another." Other comments centered on the increased ability to communicate with their group. One student stated:"By attending this institute I have learned how to break out of my comfort zone and also communicate with a team." Other students mentioned that:"I became a better communicator. I also learned new ways to get my ideas and opinions out without offending others; I have learned how to better communicate my ideas and thoughts without being afraid of rejection or sounding too bossy;" and, "I have personally benefited from this institute in many ways such as being able to communicate with others much easier and I also have found my strengths in a group."

Students who attended the Reach for Change conference also gained many skills they would need as future leaders in their communities. Through the conference, students reportedly became comfortable with the idea of sitting down with strangers, of learning about what they have in common, and of creating an interdependency that allowed them to tap into and harness the power of teamwork. Through various activities, students improved their ability to communicate in small 
groups. They learned the importance of listening to and learning from others when trying to solve problems. In this way, they were learning to think outside of the box. According to the director, what students most commonly acknowledged was their increased self-confidence. With these skills in hand, students were prepared to become leaders when they returned home.

Students' comments reflected their realization that they were gaining the abilities they needed to be better leaders within their communities. While many students were already leaders at their schools, they learned how to become better group members, a skill that allowed them to work with others to meet their goals. With many strong personalities within a single group, students were forced to create a balance that allowed the team to achieve its goal. The conference provided an environment in which those who were typically quieter gained the confidence they needed to make their voices heard. Through the workshops they attended, students gained valuable information on the various steps that are necessary for project implementation.

\section{Diversity}

Both leadership conferences, decided to include, albeit to varying degrees, diversity as a component of their institutes. The two different approaches employed by the conferences revealed extremely varying student outcomes. In the case of the Go the Distance conference, diversity not only included race and ethnicity, but also the diversity that existed in racially homogenous schools. For example, diversity included the varying degrees of socioeconomic status represented among the student body and the breadth of activities in which the students participated, such as student government or soccer, and in contrast, those students who did not participate. The Go the Distance leadership conference incorporated diversity as a central component of their institute. When discussing the goals of the conference, Patricia stated that the goal was: "To identify a problem that they [students] see facing not just one group, but the school as a whole or the community as a whole, and then to find a way to bring together the student body to address it. And maybe not the whole student body, but to bring together representatives from every different kind of population that's put in that school to really address it." She went on to explain how the Go the Distance team made every attempt to encourage faculty advisors to pick diverse groups of students to attend the conference:

We ask faculty to bring a group of five kids obviously that represent five different kinds of groups in your school. For some schools, like when Mountain 
Valley comes, it's really hard for them to find five different kinds of kids even though they have their little groups but they're pretty homogeneous in terms of their population. Other schools say here's five kids and it's you know an athlete and a student council kid and a drama kid and a totally different franchise kid and this you know is a super, over-involved, out-ofschool sort of dance, theater, singing kid. And by the way we have six more groups that are totally not represented and we'll get them involved when we get back. Other schools are like here it is. We all look the same, we all have known each other since we were 8 [years old], but we all do some different stuff at school. We all represent ourselves in a little bit different way.

Patricia's comment typifies the devotion of Go the Distance to including all types of students in the conference and eventually all types of students in the development of the school projects.

The Go the Distance conference took this commitment to diversity a step further.They provided explicit activities highlighting racial and ethnic diversity and they encouraged other aspects of diversity through the recruitment of students from the varying groups in their schools. The institute partnered with a local university that had developed a program called the Race Project. The project focused on racial/ethnic diversity issues. With the help of personnel from that project, the Go the Distance staff broke up the school teams into discussion groups of students from different schools. The Race Project provided a discussion leader for each group of about ten students, and they dialogued about the racial issues in their schools.

The students from the Go the Distance conference overwhelmingly appreciated both the discussion of racial diversity as well as the opportunity to meet students from various racial/ethnic backgrounds. One student commented that:

Some people were like I've gotten to know a lot of people and I've become less stereotyping. I've also learned that even though you don't know a person you can still go up to them and talk about what you have in common. Because everybody is going to have something in common, no matter who you are. And even if you are different, they could have the same type of music in common or something. You can talk about it. And you can get to know each other and become friends and help each other out when you need help. 
Other students mentioned that they were not aware of the inequalities that exist in other schools and communities. As a result, they were more grateful for the schools they attended: "I have learned to appreciate what my school does have.I have also learned a lot about other schools and how our school has no diversity." One student stated that: "Mostly, I learned a lot about how different my school is from others and with doing the 'diverse groups talk' I learned a lot about other cultures and people's opinions on different subjects." Go the Distance attendees overwhelmingly appreciated the experience and wanted to take it back to their schools. These two comments from students, exemplified their gratitude for the exposure to diverse people: "I myself have learned more about other cultures, and I want to show that to my school.... My eyes have been opened to a whole new world of diversity that I had yet to see. Not only did Go the Distance show me ways/skills/tips to becoming a better leader, but (it) also showed me other people, cultures, ethnicities, and backgrounds."

In contrast to Go the Distance, diversity did not play a central role in the Reach for Change conference. Although the director expressed that the staff noticed that stereotypes were dismantled as students learned the power that diversity has, diversity itself was not really addressed. The only activity designed to highlight differences between students was called the Tolerance Troupe, a half-hour activity during which students observed performers interact. The performers took on personalities that exemplified varying forms of bigotry to expose to the audience the ignorance that is involved in buying into the stereotyping of people from religious and racial backgrounds. While students were encouraged to ask the performers questions about their portrayals of intolerant ways, the majority of the students were not engaged in the activity.

The lack of responses from students who attended the Reach for Change conference regarding their diversity session suggests that it did not have an impact on their personal development. Conversely, students who attended the Go the Distance conference were extremely influenced by their diversity session. Since the Go the Distance conference provided professionals, who were trained to discuss issues of race and ethnicity, and provided the students with a more intimate setting to discuss these sensitive subjects, the experience was more meaningful. Every student was given the opportunity to share his/her opinions and experiences about interacting and sharing in a diverse world. However, as mention above the Reach for Change conference presented a play for the 200 students who attended the conference and provided very little opportunity for all students to fully participate in the discussion that followed the theatrical performance. Both youth conferences 
believed that the exposure to issues of diversity was an important element to include in their institutes. However, the varying approaches used to accomplish this goal resulted in two very different outcomes.

\section{Synergy of Outcomes}

Although the outcomes described in this paper are presented in four distinct categories (i.e., agency, belonging, competence, and diversity) many students' reports of the benefits of the conference encompassed all three aspects of youth development. Students did not talk about their outcomes in separate categories, and the evidence suggests that these aspects of youth development are not mutually exclusive. For example, one student commented that as a result of the conference: "I have learned that I need to realize when I need to stop leading/talking and listen to my group members. I have met new people and improved the bonds between my teammates. The icebreakers and fun activities were awesome, and our group is taking them back to our school to use as a part of our project." The student's comment includes aspects of agency, belonging, and competence. In this section of the paper, examples of how students described their growth as a result of the Go the Distance and Reach for Change conferences will be examined.

Students from the Go the Distance conference expressed that the sessions touched on all aspects of youth development described above. One student commented that: "I have become a little less shy and more willing to talk to strangers and people that I don't know. Also now I feel more comfortable talking about race and diversity. Also I learned how to be more of a leader than what I already am." Other similar comments included:

I have benefited in many ways from this institute. I learned not only to be a good listener, but also responsible and know when to be a leader. I learned when to step up and when to step back. Through icebreaker activities, I learned how to be more open to new people, especially through the diversity seminar.

Another student reported that: "I have benefited from the institute a lot. I learned a lot about communication, diversity, and myself. The thing I benefited the most from was making a lot more friends!" Two other Go the Distance attendees commented that: "All kinds of benefits, such as communication, leadership skill, work with diverse group and especially making friendship with other backgrounds," and "My eyes have been opened to a whole new world of diversity that I had yet to see. Not only did Go 
the Distance show me ways/skills/tips to becoming a better leader but also showed me other people, cultures, ethnicities, and backgrounds." These statements from the Go the Distance students exemplify how they benefited from the conference and how these benefits encouraged other outcomes.

Similarly, students who attended Reach for Change demonstrated agency, belonging, and competence in a way that made each component inextricable from the others; this synergy of outcomes was most strongly demonstrated by Jerry, a tenth-grade student who attended the Reach for Change conference (see Figure 1). At the beginning of the conference, Jerry refused to participate in most activities, sitting sullenly in the corner with his headphones on his ears. He claimed that the only reason he attended Reach for Change was "to get out of the house." Nevertheless, by the end of the conference, the change in Jerry was obvious. He took the initiative to sign up for the talent show, something he said he would have never had the courage to do before. Such initiative demonstrated the sense of agency he had gained. Jerry chose to dedicate the song he performed to the friends he had made at the conference and, in particular, the members of his group, saying, "Thank you, guys. Without the support I felt from you, I would not have had the courage to even sign up for [the show]." He expressed to his mentor at the conference that this was the first time he had felt like he was not being judged and actually belonged. While he did not articulate the sense of competence he had gained, in observing him, it was clear that he had gained several new skills that allowed him to interact more effectively with others. One of the conference coordinators described the transformation, saying Jerry was:

...a kid who had his headphones on, his head down, and he was really not wanting to be there, but then by Saturday he was participating and was dancing at the dance. You know, it seemed like he was really excited to be there.

The synergy of the three aspects of youth development in Reach for Change served to create positive outcomes for Jerry and the other conference participants. 
Agency:

Jerry had the courage

to sign up for the

talent show.

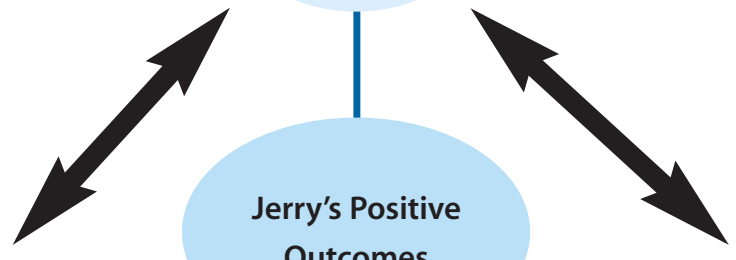

Outcomes

Belonging:

Jerry expressed that he did not feel judged, for the first time.
Competence:

Jerry was able to communicate effectively with team members.

Fig. 1: Synergy of youth development outcomes

\section{Discussion}

As the national educational agenda continues to focus on accountability and as schools continue to focus on standardized tests, students need an outlet to develop positive emotional and personal characteristics. The findings from this research suggest that student leadership conferences can help fill this void for youth. By providing young people with time away from the rigidity of "schooling," students who attend leadership conferences are able to develop a sense of agency and belonging. Youth are also given the opportunity to develop a range of competencies, and to a varying degree, an understanding and appreciation for diversity.

The findings of this research suggest that some best practices for developing the $A B C D$ 's in youth occur through leadership conferences. For example, both the Go the Distance conference and the Reach for Change conference culminated with the creation of a group project. In the case of the Go the Distance conference, students 
from the same school, who may not have known each other prior to the conference, were responsible for developing a project that would address a social problem in their school or in their community. Students who attended the Reach for Change conference may have come from the same school, but were grouped into teams of 10 with students who had similar interests in a social problem in their community. Many students were in groups with students who did not go to the same school. The group project or team aspect of these conferences allowed youth to connect with a small group of students on an intimate level. The project provided students with opportunities to voice their opinion and for students to alternately take the lead with the project, thereby helping young people to develop a sense of agency.

However, the Go the Distance conference took the group project component of the conference a step further. The conference required the youth to actually implement their projects once they returned to their schools. The project implementation provided them with increased opportunities for development. Many of the youth projects required more than a team of five to implement them, and often the projects were focused on building community within their school. Students from the Go the Distance conference had to recruit other students from their schools to assist in the further development and implementation of the project. It was assumed that all the students who attended the conference would take on a leadership role once they returned to their schools. In the past, some projects have stayed with youth for their entire school year. The group project experience allowed for further and long-lasting development of the ABCD's of youth because they had to use what they had learned and the new skills they had developed. Students were able to demonstrate the change and growth that they experienced through the conference. By taking on leadership roles in their schools and working with others, they continued to develop agency, belonging, competencies, and exposure to diversity. The group project component allowed for further synergy of the youth development outcomes through the continued responsibility they had for working with others and being a leader among their peers. Thus, this project exemplifies a youth development program grounded in a community youth development framework.

It was more difficult, however, for students who attended the Reach for Change conference to implement their projects because (1) there was no expectation to complete their projects and, (2) once they returned to their schools, their team members were scattered all over central Pennsylvania. This particular conference mirrors one-shot, youth programs that may include some important youth development aspects, but are not based on a community youth development framework. 
Both Go the Distance and Reach for Change included a mentorship component in the structure of their conferences, albeit in very different ways. The Go the Distance conference requested that a faculty member from each school attend the conference and assist students in seeing through their projects. The faculty mentor component of the conference provided an extremely positive dimension for the youth participants. The experience of working with an adult helped them develop a stronger sense of agency. In the development of the group project, students were able to voice their opinions and even disagree with an authority figure. At the Go the Distance conference, as well, the hierarchical teacher-student relationship was flattened, so that students and faculty were on a more level playing field. Students felt empowered by working as equals with faculty as equals as opposed to being treated like children. The faculty mentorship also allowed youth and students to become better acquainted with each other. Once students returned to their schools, they felt an increased sense of belonging because they now had a faculty ally.

The Reach for Change conference developed an alternative mentorship model. Known as Near Peers and Near Peer Interns, the mentors at Reach for Change provided guidance for youth during the conference as described earlier in this paper. Near Peers and Interns participated in an intense training and teambuilding session before the youth arrived. They presented a united and emotionally connected front, while helping students develop a sense of self. The Near Peers and Interns provided youth with a concrete example of young people who have developed a sense of agency, belonging, and a variety of competencies. Many of the Near Peers and Interns had known each other for many years and their relationship exemplified the importance of belonging and sustaining meaningful friendships. Allowing Reach for Change attendees to continue their participation in the conference by becoming future Near Peers and Interns built a network of conference attendees that continued for years to come. It offered youth the opportunity to continue to develop the personal characteristics described in this study through early adulthood.

The findings also suggest that the inclusion of diversity in the $A B C$ 's of youth development is an appropriate addition. In the case of the leadership conferences described in this study, diversity is defined as groups of people from various racial/ethnic backgrounds, religions, income levels, and the many social groups that exist in schools, such as athletes, or students who are not involved in any extracurricular activities. Little research on youth programs to promote community youth development addresses the importance of diversity and cultural competence (Eccles \& Gootman, 2002; Pittman, 1991). When diversity issues are discussed within the framework of youth leadership conferences, it is described as an avenue to help youth 
develop a sense of belonging (Eccles \& Gootman, 2002). However, the Go the Distance conference incorporated diversity issues on a much deeper level. Not only did this conference provide youth with an opportunity to discuss their feelings and experiences with diverse groups of people, but also it purposely sought out diverse groups of students to take part. The diversity session at the conference suggested that when youth are given the opportunity to discuss issues of diversity in small groups, youth enjoy a meaningful experience. Students who attended the Go the Distance conference overwhelmingly indicated that they appreciated the discussions on diversity and the opportunity to meet different people who attended schools unlike their own. This experience expanded their frames of reference and their knowledge about the diversity that exists not even an hour away from their homes. It also broke down barriers. Students realized that they had more in common with people they once considered "different."

Future research on youth development and organizations considering developing youth conferences should focus on the four aspects of youth development: agency (A), belonging (B), competence (C), and diversity (D). Lastly, this study reveals that the four components of youth development do not occur in isolation from one another. For example, it appears that a sense of belonging can be influenced by the development of agency, the increased ability to communicate (competency), and the exposure to diversity. A plausible argument can be developed to explain how any one outcome influences the other. This finding suggests that youth conferences should make every attempt to encourage the development of all four components in order to maximize outcomes. Youth conference organizers should develop activities and personal development seminars that encourage the development of ABCD's in youth in concert with one another. Finally, and probably most difficult, given resource limitations, follow-up and "booster" sessions and/or technical assistance may be more likely to increase the sustainability of the outcomes.

\section{Conclusion}

Just as youth development scholars found that the emphasis on prevention does not adequately describe the skills youth need for the future (Cahill, 1997; Connell, Gambone, \& Smith, 1998, Perkins \& Caldwell, 2005; Pittman \& Cahill, 1992, Pittman \&Wright, 1991), the research presented here suggests that the ABC's of youth development no longer suffice. In simply focusing on agency, belonging, and competency, institutions and organizations may fail to help students realize their full 
potential. In conceptualizing the types of changes that one might see as youth participate in leadership activities, a better understanding of youth development is necessary.

As institutions and organizations work to meet the developmental needs of adolescents, it may be necessary to expand current views on student outcomes to include a " $\mathrm{D}$ " for diversity and cultural competence. For some students, the conferences are the first opportunity they have had to interact with others whose views do not necessarily align with their own. By exposing youth to students with different life experiences, the conferences prepare youth for the increasing diversity they will encounter when they go out into the world. Students need to be able to participate in discussions of diversity in a "safe" environment, an environment that encourages open-mindedness where youth will not be judged. When this opportunity is afforded youth, some of the challenges diversity may pose for them in the future can be overcome. Institutions and organizations can provide youth with skills that will help them to lead successful lives in a diverse society.

Groups that are interested in youth development would also benefit from gaining a deeper understanding of how the synergy of agency, belonging, competence, and diversity affects the outcomes for youth. Although these components of youth development are considered to develop in isolation, the true outcomes for students are the result of the synergistic intertwining of these dimensions. To meet the developmental needs of youth, institutions and organizations must determine how to include each of these four elements into their youth development conferences. While this is not to say that every activity must involve the ABCD's of youth development, this study suggests that those that do will have the greatest impact upon youth.

As schools increasingly succumb to the pressure to equate student outcomes with test scores, society will need to provide students with other opportunities to learn how to become citizens prepared to actively engage in their communities and to participate in democracy. The youth leadership conferences discussed in this paper described two such opportunities. In helping students to acquire the ABCD's of youth development, and by taking advantage of how these four components converge, Going the Distance and Reach for Change helped to re-engage students and gave them the self-esteem and power they were not receiving in schools. In this way, conferences can help students become engaged and contributing citizens. 


\section{References}

Becker, H. S. (1998). Tricks of the trade: How to think about research while you're doing it. Chicago:The University of Chicago Press.

Cahill, M. (1997, April). Youth development and community development: Promises and challenges of convergence. Paper presented at the Community and Youth Development: Complementary or Competing Priorities for Community Development Organizations, Princeton, NJ.

Carver, R. L. (1997). Theoretical underpinnings of service learning. Theory into Practice, 36(3), 143-149.

Connell, J. P., Gambone, M. A., \& Smith, T. J. (1998). Youth development in community settings: Challenges to our field and our approach. Rochester, NY: Institute for Research and Reform in Education.

Costello, J., Toles, M., Spielberger, J., \& Wynn, J. (2000). History, ideology and structure shape the organizations that shape youth. In Youth Development: Issues, Challenges, and Directions (pp. 185-231). Philadelphia: Public/Private Ventures.

Cothran, D., \& Ennis, C. (2000). Building bridges to student engagement: Communicating respect and care for students in urban schools. Journal of Research and Development in Education, 33(2), 106-117.

Dewey, J. (1916/1966). Democracy and Education: An Introduction to the Philosophy of Education. New York: The Free Press.

Earls, F. (2003). Age segregation and the rights of children. Ann Arbor, MI: Society for Research in Child Development.

Eccles, J., \& Gootman, J. A. (2002). Community programs to promote youth development. Committee on Community-Level Programs for Youth. Board on Children, Youth, and Families, Commission on Behavioral and Social Sciences Education, National Research Council and Institute of Medicine. Washington, DC: National Academies of Science.

Eccles, J. S., Midgley, C., Wigfield, A., Buchanan, C. M., Reuman, D., Flanagan, C., et al. (1993). Development during adolescence: The impact of stage-environment fit on young adolescents' experiences in schools and in families. American Psychologist, 48(2), 90101.

Fielding, M. (2001). Students as radical agents of change. Journal of Educational Change, 2(2), 123-141.

Flanagan, C., \& Faison, N. (2001). Youth civic development: Implications of research for social policy and programs. Ann Arbor, MI: Society for Research in Child Development.

Fullan, M. G. (2001). The new meaning of educational change (3rd ed.). New York: Teachers College Press.

Goodenow, C. (1993). Classroom belonging among early adolescent students: Relationship to motivation and achievement. Journal of Early Adolescence, 13(1), 21-43.

Goodwillie, S. (Ed.). (1993). Voices from the future: Our children tell us about violence in America. New York: Crown Publishers.

Heath, S. B., \& McLaughlin, M. W. (Eds.). (1993). Identity and inner-city youth. New York: Teachers College Press.

Honig, M., Kahne, J., \& McLaughlin, M.W. (2001). School-community connections: strengthening opportunity to learn and opportunity to teach. In V. Richardson, (Ed.), Handbook of research on teaching (4th ed., pp. 998-1028). Washington, DC: American Educational Research Association.

Kernaleguen, A. (1980). Clothing: An important symbol for adolescents. School Guidance Worker, 35(3), 37-41.

Kirshner, B. (2004). Democracy now: Activism and learning in urban youth organizations. Stanford, CA: Stanford University.

Kirshner, B., O'Donoghue, J. L., \& McLaughlin, M. W. (Eds.). (2003). New directions for youth development: Youth participation improving institutions and communities. San Francisco: Jossey-Bass.

Larson, R.W. (2000). Toward a psychology of positive youth development. American Psychologist, 55(1), 170-183. 
Lerner, R. M. (2004). Liberty: Thriving and civic engagement among America's youth. Thousand Oaks, CA: Sage.

McLaughlin, M.W. (1999). Community counts: How community organizations matter for youth development. Washington, DC: Public Education Network.

Miles, M. B., \& Huberman, A. M. (1994). Qualitative data analysis. Thousand Oaks, California: Sage.

Mitra, D. L. (2003). Student voice in school reform: Reframing student-teacher relationships. McGill Journal of Education, 38(2), 289-304.

Mitra, D. L. (2004). The significance of students: Can increasing "student voice" in schools lead to gains in youth development? Teachers College Record, 106(4), 651-688.

Mitra, D. L. (2007). Student voice in school reform: From listening to leadership. In D. Thiessen \& A. Cook-Sather (Eds.), International Handbook of Student Experience in Elementary and Secondary School. (pp. 727-744). Dordrecht, The Netherlands: Springer.

National Alliance for Secondary Education and Transition (2005). The College of Education and Human Development, University of Minnesota. Retrieved on September 3, 2007 from http://www.nase talliance.org/youthdev/index.htm

Noguera, P. (2002, December). Joaquin's dilemma: Understanding the link between racial identity and school-related behaviors. In Motion Magazine. Retrieved April 29, 2004, from http://www.inmotionmagazine.com /er/pnjoaq2.html

Oldfather, P. (1995). Songs "come back most to them": Students' experiences as researchers. Theory Into Practice, 34(2), 131.

Perkins, D. F., Borden, L. M., Keith, J. G., HoppeRooney, T., \& Villarruel, F. A. (2003). Community youth development: A partnership for creating a positive world. In F. A. Villarruel, D. F. Perkins, L. M. Borden, \& J. G. Keith, (Eds.), Community Youth Development: Practice, Policy, and Research (pp. 1-23). Thousand Oaks, CA: Sage.
Perkins, D. F., \& Caldwell, L. (2005). Resiliency, protective processes, promotion, and community youth development. In P. Witt \& L. Caldwell (Eds.), Recreation and youth development (pp. 149-167). State College, PA: Venture.

Pittman, K. J., \& Cahill, M. (1992). Pushing the boundaries of education: The implications of a youth development approach to education policies, structures, and collaborations (No. Ed 366 880). Washington, DC: Academy for Educational Development.

Pittman, K., Irby, M., \& Ferber, T. (2000). Youth as effective citizens: Background report and recommendations. Washington, DC: International Youth Foundation.

Pittman, K. J., \& Wright, M. (1991). Bridging the gap: A Rationale for enhancing the role of community organizations in promoting youth development. Washington, DC: Carnegie Council on Adolescent Development.

Pope, D.C. (2001). "Doing school": How we are creating a generation of stressed out, materialistic, and miseducated students. New Haven, CT:Yale University Press.

Roeser, R. W., Midgley, C., \& Urdan, T.C. (1996). Perceptions of the school psychological environment and early adolescents' psychological and behavioral functioning in school: The mediating role of goals and belonging. Journal of Educational Psychology, 88(3), 408-422.

Roth, J., \& Brooks-Gunn, J. (2000). What do adolescents need for healthy development? Implications for youth policy. Social Policy Report, 14(2), 423-459.

Rudduck, J., \& Flutter, J. (2000). Pupil participation and perspective:'Carving a new order of experience'. Cambridge Journal of Education, 30(1), 75-89.

Schaps, E., Watson, M., \& Lewis, C. (1997). A key condition for character development: Building a sense of community in school. Social Studies Review, 37(1), 85-90.

Stinson, S. W. (1993). Meaning and value: Reflections on what students say about school. Journal of Curriculum and Supervision, 8(3), 216-238. 
Strauss, A., \& Corbin, J. (1990). Basics of qualitative research: Grounded theory procedures and techniques. Newbury Park, CA: Sage.

Takanishi, R. (1993). Changing views of adolescence in contemporary society. In R. Takanishi (Ed.), Adolescence in the 1990s: Risk and opportunity (pp, 1-7). New York: Teachers College Press.

Villarruel, F. A., \& Lerner, R. M. (Eds.). (1994). Promoting community-based programs for socialization and learning. San Francisco: Jossey-Bass.

Villarruel, F. A., Perkins, D. F., Borden, L. M., \& Keith, J.G. (2003).Community youth development: Practice, policy, and research. Thousand Oaks, CA: Sage.
Zeldin, S. (2004). Youth as agents of adult and community development: Mapping the processes and outcomes of youth engaged in organizational governance. Journal of Community Psychology, 8(2), 7590.

Zeldin, S., Camino, L., \& Mook, C. (2005). The adoption of innovation in youth organizations: Creating the conditions for youthadult partnerships. Journal of Community Psychology, 33(1), 121-135.

Zeldin, S., McDaniel, A. K., Topitzes, D., \& Calvert, M. (2000). Youth in decision making: A study on the impacts of youth on adults and organizations. Madison, Wisconsin: Innovation Center/Tides Center: University of Wisconsin Extension.

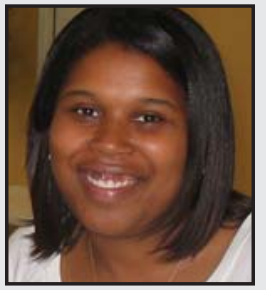

Felicia C. Sanders is a Ph.D. student in the Education Theory and Policy program at the Pennsylvania State University. Her research interests include urban education, high school reform, and policy implementation.

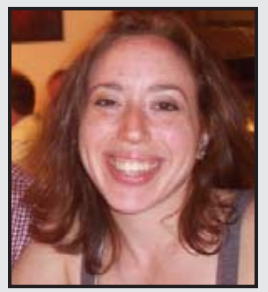

Marcela Movit received her M.Ed. in Bilingual Education from the University of Houston in 2003 and her Ph.D. in Educational Theory and Policy from the Pennsylvania State University in 2007. Her research focuses on language policy in schools with special consideration given to the issue of equal educational opportunity for language minority students from diverse backgrounds. She currently holds a position with the Institute for the Study of Adult Literacy. 


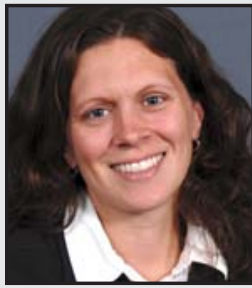

Dana L. Mitra is Assistant Professor in the department of Education Policy Studies at the Pennsylvania State University. She holds a Ph.D. from Stanford University in Educational Administration and Policy Analysis. Her research interests include student voice, youth-adult partnerships, and high school reform.

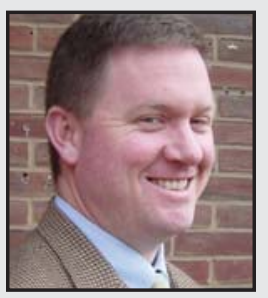

Daniel F. Perkins is a Professor of family and youth resiliency and policy in the Department of Agricultural and Extension Education at the Pennsylvania State University. Dr. Perkins work involves teaching, research, and outreach through the Penn State Cooperative Extension Service. His scholarship involves the integration of practice and research into three major foci: (1) Positive Youth Developmentdecrease risks and increase skills and competencies of youth; (2) Healthy Family Development-increase resiliency through strength-based educational programming; and (3) Community Collaboration-promote strategies for mobilizing communities in support of children, youth, and families.

LINK TO:

http://cyfar.cas.psu.edu/PDFs/yesbookweb.pdf

http://resiliency.cas.psu.edu

http://www.ed.psu.edu/edthp/Faculty\%20Bios/mitra.asp 